Reprod. Nutr. Dévelop., 1982, 22 (6), 1049-1060.

\title{
Effects of long-term ad libitum feeding on the voluntary food intake, body weight, body composition and adipose tissue morphology of lean adult sheep
}

\author{
Françoise VANDERMEERSCHEN-DOIZE, \\ Marie-Antoinette BOUCKOMS-VANDERMEIR, R. PAQUAY \\ Laboratoire de Physiologie animale, Facultés Universitaires de Namur, \\ rue de Bruxelles 61, B-5000 Namur, Be/gium.
}

Summary. An experiment was conducted in which adult Suffolk ewes were given an ad libitum diet for 9 months and then compared with control sheep fed a maintenance diet. The changes in body weight and food intake could be divided into three phases. In the first phase, a high food intake 3-3.5 times the maintenance level corresponded to a high body weight gain of more than $200 \mathrm{~g} /$ day. In the second phase, body weight also increased, but voluntary food intake decreased. In the last phase, a stable body weight was associated with a decreased food intake. More than 6 months elapsed before this stability was reached.

After a prephase, characterized by a large increase of body water, ad libitum feeding induced fat deposition with a consequent increment in body fat from 9 to 37 p. 100 of live weight. The total amounts of body water, mineral matter and protein remained stable but their relative amounts (in percent of live weight) decreased. The body weight of each sheep stabilized at a determined level of body fat $(25-50 \mathrm{~kg})$; the relative amounts were less variable (35-42 p. 100 of live weight).

During the first 18 weeks of ab libitum feeding, both control and experimental sheep achieved the same mean fat cell weight $(0.14 \mu \mathrm{g})$. Between the 18th and $22 \mathrm{nd}$ week a rapid increase was observed in the experimental sheep (mean \pm SD : $0.37 \pm 0.15 \mu \mathrm{g}$ ), followed by stable values until the end of the test.

The unimodal adipocyte size frequency distribution remained unaffected in the control group ; the adipocytes of the experimental group shifted towards a bimodal distribution, showing an increase in the proportion of small cells (S1), a decrease in the proportion of medium-sized cells (S4, S5) and the appearance of large cells (S6 to S9). These results seem to indicate close interrelationships between voluntary food intake, body weight and body compositon in sheep.

\section{Introduction.}

Some experiments (Panksepp, 1975 ; Bell, 1976 ; Van Itallie et al., 1977 ; Keesey et al., 1979) indicate that body weight and the quantity of body fat reserves, closely related in simple-stomached animals, are involved in the longterm control of food intake. But the exact mechanism whereby the body fat reserves act on the central nervous system controlling the food intake is still not well known. 
Due to ad libitum feeding of ruminants, relatively little information is available on the changes in adult body composition and on the influence of body fat on voluntary food intake. Graham (1969) demonstrated that the voluntary food intake in sheep began to decline with fatness. Forbes (1977), in a model for predicting patterns of food intake in adult sheep, postulated that sheep offered food ad libitum have a stable intake at high levels of fatness.

The first step in trying to elucidate the mechanism controlling voluntary food intake in ruminants was to determine and compare the profiles of voluntary food intake, body composition and various substances. In the present study we used the following design. Two long-term experiments were programmed with lean adult Suffolk sheep receiving food ad libitum for several months. Food intake, body weight, body composition, blood factors (different blood lipid constituents, glucose, $\beta$-hydroxybutyrate, insulin) and adipose tissue factors (mean fat cell weight, adipocyte size frequency distribution) were regularly monitored. Similar results were obtained for both experiments; the present paper presents the results of one of them.

\section{Material and methods.}

Eleven non-pregnant, non-lactating Suffolk ewes more than 2 years old were housed in individual boxes and maintained under natural light and temperature conditions.

Before the experiment started, they were fed a sub-maintenance diet for several months and their body weight fluctuated between 50 and $60 \mathrm{~kg}$ (normal body weight: $70-80 \mathrm{~kg}$ ). During a two-week pre-experimental period, all the sheep received $300 \mathrm{~g}$ of pasture hay and $500 \mathrm{~g}$ of a commercial mixture. From August on and during the next 9 months, the sheep were divided into two groups, a control group of 3 ewes (T1-T3) and an experimental one of 8 ewes (E1-E8). All the ewes were fed individually. The control group received $300 \mathrm{~g}$ of pasture hay and $500 \mathrm{~g}$ of a concentrate mixture. The experimental group was fed ad libitum with the same pasture hay and concentrate mixture for 39 weeks, the food residues being removed and weighed weekly. The sheep were also weighed weekly on Thursday and Friday at 09.30 a.m.

The concentrate given during the 9-month experimental period was a pelleted mixture containing 40 p. 100 dried sugar beet pulp, 30 p. 100 dehydrated lucerne (Medicago sativa) and 30 p. 100 cereals; it included 89.3 p. 100 dry matter obtained by oven drying, 7.1 p. 100 mineral matter obtained by ashing at $600{ }^{\circ} \mathrm{C}$ for $12 \mathrm{~h}, 11.0$ p. 100 protein (nitrogen $\times 6.25$ ) determined by Kjeldahl's method and 10.8 p. 100 crude fibre determined by Weende's method. Pasture hay was composed of 90.2 p. 100 dry matter, 9.3 p. 100 mineral matter, 10.3 p. 100 protein and 26.6 p. 100 crude fibre.

Body composition and adipocyte morphology were determined every 4 weeks starting at the 3 rd week of the experimental period. Body composition was estimated from the tritiated water space and live weight by the method described in Doizé et al. (1979 b) with some modifications. Food and water were 
not removed and urine was not sampled. Jugular blood samples were taken 24, 48 and $72 \mathrm{~h}$ after the administration of tritiated water to ensure a better estimation of the diffusion of tritiated water.

Adipose tissue biopsies and adipocyte morphology were studied as follows. After local subcutaneous anesthesia ( $5 \mathrm{ml}$ of Procain) about $1 \mathrm{~g}$ of subcutaneous fat was excised from the tailhead of the sheep using the technique described by Johnson et al. (1977). Isolated fat cells were prepared according to the method of Rodbell (1964). Cell incubation was carried out at $40{ }^{\circ} \mathrm{C}$ in Krebs-Ringer bicarbonate buffer $(\mathrm{pH} 7.4)$ with half the recommended concentration of $\mathrm{Ca}^{2+}$, $6 \mu \mathrm{M} / \mathrm{ml}$ glucose and $35 \mathrm{mg} / \mathrm{ml}$ of fatty acid-poor bovine albumin (Calbiochem). In order to avoid disruption, the larger cells were not washed but were examined immediately. The fat cell diameter was determined using the photomicrographic technique of Lavau et al. (1977).

The diameter of about 500 cells was measured and grouped into nine size classes (S1 to S9) as follows : up to $30,30-60,60-90,90-120,120-150,150-180$, $180-210,210-240,240-360 \mu$. The mean proportions for each size class were calculated and graphically represented for both groups of sheep. A modified chisquare test (Kaplan et al., 1976) was performed. The average proportions for each size class were multiplied by the average number of total cells counted per sample. This calculated average population distribution was submitted to a normal chi-square test. The adipocyte sizes S1 to S5 were submitted to an analysis of variance.

Mean fat cell weight was calculated according to the formula developed by Hirsch and Gallian (1968).

\section{Results.}

Fattening phases. - The results of all the parameters were related to time, body weight and cumulated food intake, and all the parameters that did not vary were thus eliminated. Thereafter, we visually examined the remaining parameters and divided them into three fattening phases : phase 1 lasting 7 weeks (from the 4th to 10th week), phase 2 lasting 13 weeks (from the 14th to 26th week) and phase 3 coinciding with the final 9 weeks. Phase 1 was preceded by a 3-week prephase, and there were a few weeks of transition between phases 1 and 2 and phases 2 and 3 . The results included in the different phases were evaluated statistically by a principal component analysis of the correlation matrix. This analysis confirmed the existence of the different fattening phases.

Dietary intake. - The control sheep consumed $715 \mathrm{~g}$ dry matter/day throughout the experimental period. The changes in the dietary dry matter intake of the experimental sheep are shown on figure 1.

During the prephase there was a 3.5 -fold increase in food intake when passing from the pre-experimental diet to the experimental diet. In phase 1 , food intakes were particularly high, reaching a mean of $2404 \mathrm{~g}$ dry matter/day. In phase 2, food intakes remained high but decreased by $25.7 \mathrm{p}$. 100. Phase 3 was also characterized by a decrease in food intake. 


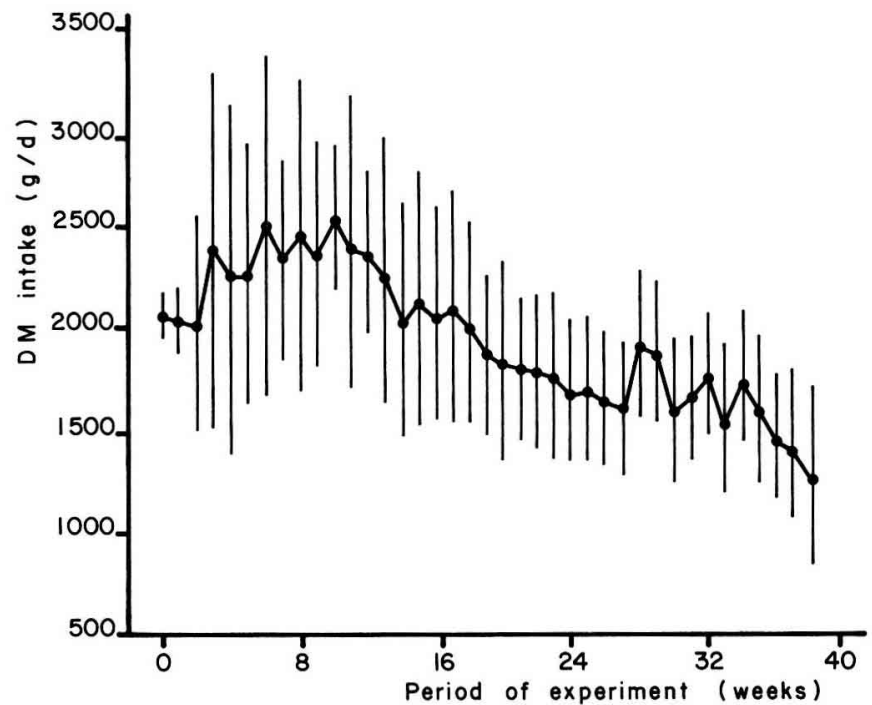

FIG. 1. - Changes in dry matter intake (g/day) in ad libitum fed sheep. Weeks -2 to 0 correspond to the pre-experimental period and weeks 1-39 to the experimental period.

The concentrate represented 85 p. 100 of the total daily food consumption of the ad libitum fed sheep at the beginning of the experiment and $75 \mathrm{p} .100$ by the end.

Body weight. - The body weight of the control sheep remained stable throughout the experiment (mean of $54.0 \mathrm{~kg}$ ). The changes in body weight in the experimental group are shown on figure 2 . Initial body weight fluctuated

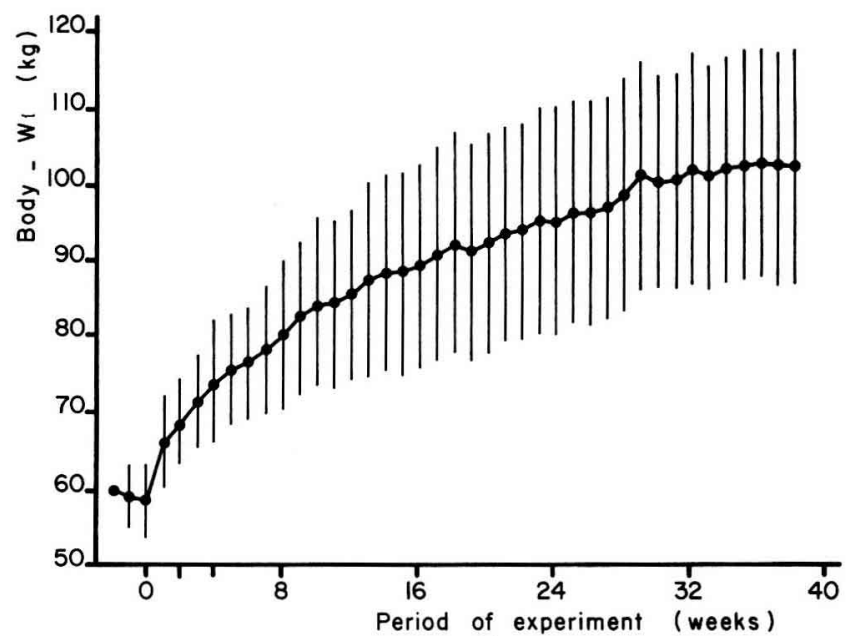

FIG. 2. - Changes in body-weight in ad libitum fed sheep. Weeks -2 to 0 correspond to the pre-experimental period and weeks 1-39 to the experimental period. 
around $60 \mathrm{~kg}$. During the prephase, when passing from the pre-experimental to the experimental diet, all the sheep gained weight rapidly. This mainly corresponded to the high quantity of food in the reticulo-rumen. Phase 1 corresponded to a high body weight gain (mean of $210 \mathrm{~g} /$ day). The body weight gain of phase 2 represented only 44 p. 100 of that occurring in phase 1 , and phase 3 was characterized by stable body weight. It was 8 months before a specific level of stability was reached by each sheep.

Body composition. - Because of the slow elimination of the injected tritiated water, tests were carried out every month (Robelin, 1973). The data we obtained could not be subdivided into different phases.

Body fat. - The body fat of control sheep remained stable throughout the experiment (mean content : $9.07 \mathrm{~kg}$ or 16.80 p. 100 of live weight).

The values for the experimental group are shown on figure 3 . The mean fat content of the experimental sheep at the beginning of the test was $7.09 \mathrm{~kg}$ (9.2 p. 100 of live weight). Until the 15th week of the experiment, the fat gain was high for all the experimental sheep (mean of $259 \mathrm{~g} /$ day). At the end of the experiment, the body fat content of the experimental sheep remained stable, but large differences between sheep were observed, ranging from about 25 to $50 \mathrm{~kg}$ of fat. During the last three tests (weeks 31,35 and 39) the mean body fat content (37 p. 100 of live weight) only fluctuated between 35 and 42 p. 100.

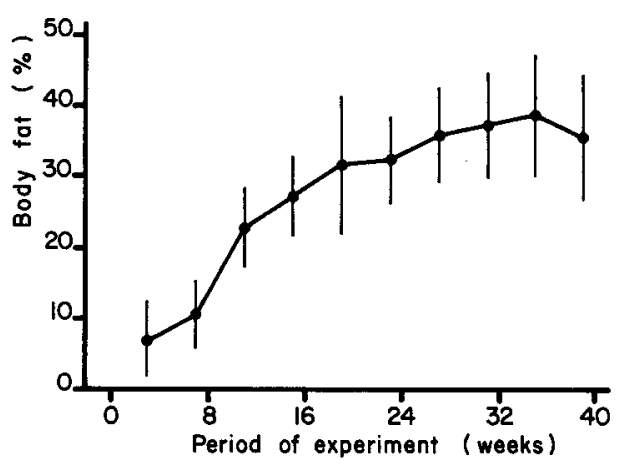

FIG. 3.

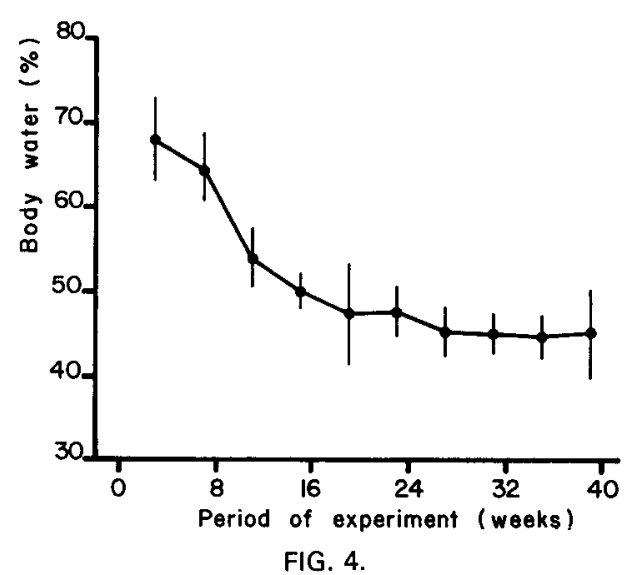

FIG. 4.

FIG. 3. - Changes in the quantity of body fat in ad libitum fed sheep. Weeks -2 to 0 correspond to the pre-experimental period and weeks $1-39$ to the experimental period.

FIG. 4. - Changes in the body water content in ad libitum fed sheep. Weeks -2 to 0 correspond to the pre-experimental period and weeks 1-39 to the experimental period.

Body lean, water, protein and mineral matter. - In control sheep these body components did not vary during the experiment and had a mean value of $44.7 \mathrm{~kg}$ of lean (83.3 p. 100 of live weight), $32.9 \mathrm{~kg}$ of water $(61.4 \mathrm{p} .100$ of live 
weight), $8.1 \mathrm{~kg}$ of protein $(15.0 \mathrm{p}$. 100 of live weight) and $2.1 \mathrm{~kg}$ of minerals (3.9 p. 100 of live weight).

During the experiment, the amount of body lean and water in the experimental sheep decreased slightly $165-68 \mathrm{~kg}$ of lean and $48-50 \mathrm{~kg}$ of water in experimental weeks 3 to $7 ; 62-65 \mathrm{~kg}$ of lean and $42-45 \mathrm{~kg}$ of water from the 15th week), whereas protein $(12-13 \mathrm{~kg})$ and mineral matter $(2.8-3.2 \mathrm{~kg})$ remained stable.

The changes in the body water content of the experimental sheep are shown on figure 4. A decrease was observed during the first months of the experiment which stabilized by the end of the experiment. Body lean $(90.7 \pm 6.1$ p. 100 of live weight at week $3 ; 64.6 \pm 6.0$ p. 100 of live weight at week 39$)$, protein $(18.0 \pm 1.2$ p. 100 of live weight at week $3 ; 13.4 \pm 1.3$ p. 100 of live weight at week 39$)$ and mineral matter $(4.4 \pm 0.4$ p. 100 of live weight at week $3 ; 2.9 \pm 0.3$ p. 100 of live weight at week 39 ) content changed in the same way.

Adipocyte size frequency distribution. - The adipocyte size distribution was unimodal in control sheep throughout the experiment; the general means (in p. 100 of total cells) for the different sizes were: $\mathrm{S} 1: 35.46 \pm 9.79 ; \mathrm{S} 2$ : $25.66 \pm 6.36$; S3 : $25.91 \pm 9.11 ; \mathrm{S} 4: 8.84 \pm 4.67 ; \mathrm{S} 5: 1.72 \pm 1.71 ; \mathrm{S} 6$ : $0.58 \pm 0.83$. Cells of sizes S7, S8 and S9 contributed to less than 0.5 p. 100 of the total number of cells counted.

The profile of the adipocyte size frequency distribution of the experimental sheep is shown on figure 5 . Cells up to $\$ 12$ were found in the experimental animals, but the rate of S10 and S12 never exceeded 1 p. 100.

The adipocyte size frequency distribution of experimental and control sheep was different in every biopsy. At experimental week 2, $\chi^{2}$ had a value of 2780 (P $<0.01$ ) but reached values higher than 25000 from the 14 th week on.

At experimental weeks 2 and 6 , both groups of sheep had the same unimodal adipocyte distribution, but the experimental sheep showed a greater proportion of small cells (S1). From experimental week 10, important modifications occurred in the ad libitum fed animals. An increase in the proportion of

Analysis of variance of cell sizes S1 to S5: level of significance

\begin{tabular}{|c|c|c|c|}
\hline Adipocyte size & $\begin{array}{c}\text { Time of ad lib. } \\
\text { feeding }\end{array}$ & $\begin{array}{l}\text { Group } \\
\text { of animal }\end{array}$ & $\begin{array}{l}\text { Ad lib. feeding- } \\
\text { group interaction }\end{array}$ \\
\hline $\mathrm{S}_{1}$ & * & $* * *$ & NS \\
\hline $\mathrm{S}_{2}$ & NS & NS & $* * *$ \\
\hline $\mathrm{S}_{3}^{2}$ & NS & $* * *$ & NS \\
\hline$S_{4}$ & NS & NS & $* *$ \\
\hline $\mathrm{S}_{5}$ & * & $* *$ & $* * *$ \\
\hline
\end{tabular}

NS not significant ; ${ }^{*} \mathrm{P}<0.05 ;{ }^{*} \mathrm{P}<0.01 ;{ }^{* *} \mathrm{P}<0.001$. 

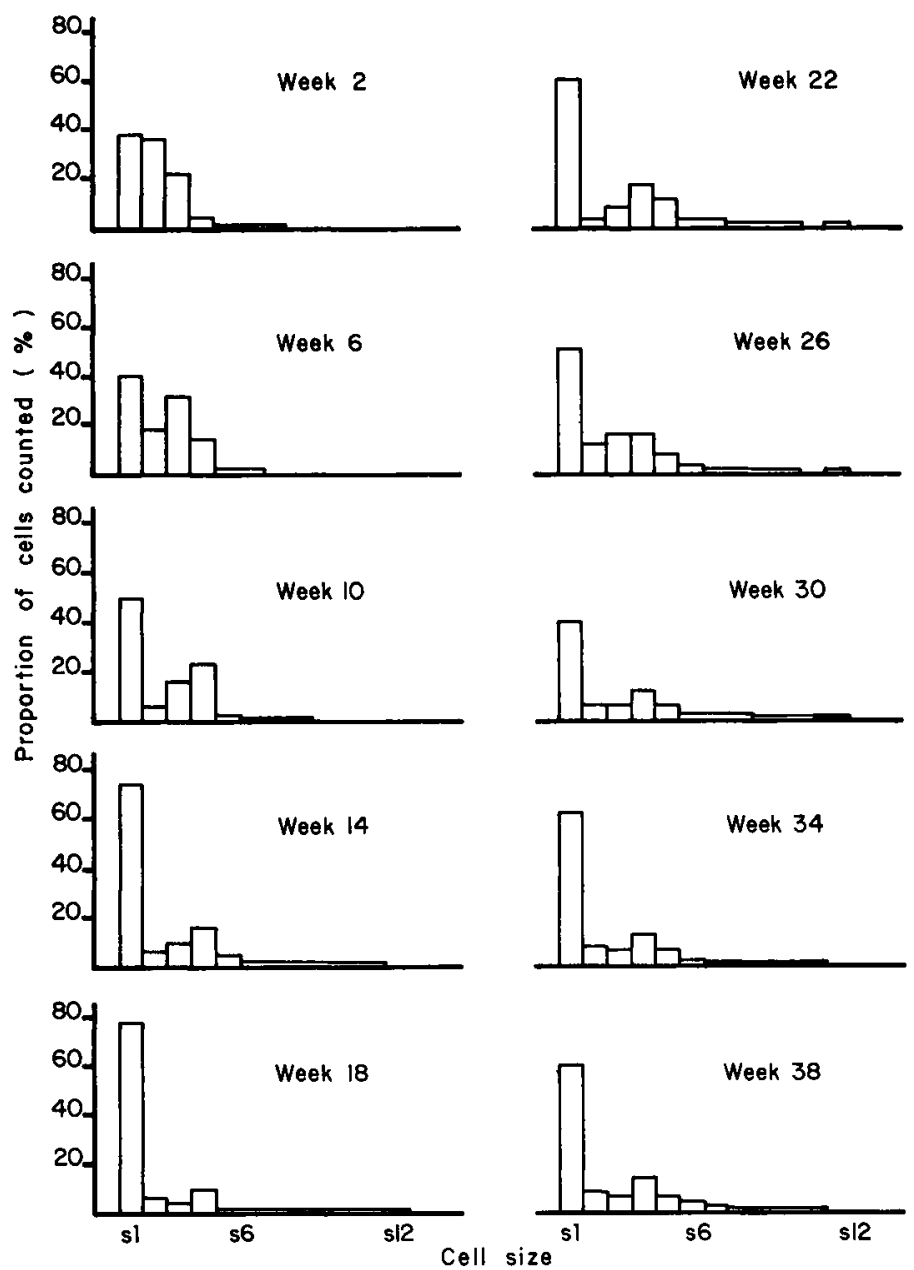

FIG. 5. - Adipocyte size frequency distribution in experimental sheep. $\mathrm{S} 1$ to $\mathrm{S} 9$ refers to twelve size classes: up to $30,30-60,60-90,90-120,120-150,150-180,180-210,210-240,240-260$, 260-290, 290-310, 310-340 $\mu$.

small cells (S1) was associated with a decrease in the proportion of mediumsized adipocytes and the appearance of larger ones. The proportions of the size classes in descending order of magnitude were : S1, S4, S5, S3, S2. During the next two observations a slight decrease of $\mathrm{S} 1$ was balanced by an increase of the larger cells. The last three observations were characterized by a stable bimodal adipocyte frequency distribution.

The analysis of variance (table 1) confirmed that feeding ad libitum induced an increase in the proportions of small and large cells.

Mean fat cell weight. - The average cell weight (in $\mu \mathrm{g}$ ) of the control sheep remained stable throughout the test $(0.14 \pm 0.04)$. 
Figure 6 illustrates the changes in the mean fat cell weight in the experimental sheep. Up to 18 weeks of ad libitum feeding, the experimental sheep achieved the same value as the control group. A rapid decrease was observed between the 18th and 22 nd weeks $(0.27 \pm 0.15)$, and thus during phase 2 . Thereafter, the mean value remained stable.

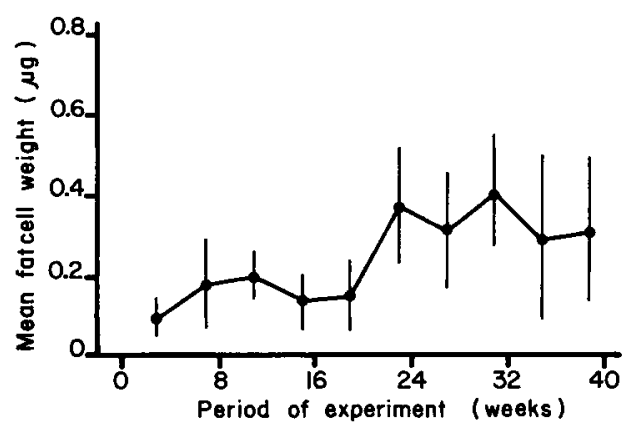

FIG. 6. - Mean fat cell weight in ad libitum fed sheep. Weeks -2 to 0 correspond to the pre-experimental period and weeks 1-39 to the experimental period.

\section{Discussion.}

The results of the present study demonstrated a relationship between food intake, body weight, body composition and adipocyte morphology.

When feeding lean adult sheep ad libitum, the fattening period could be divided into three successive phases. The first phase corresponded to high food intake ( $2404 \mathrm{~g} /$ day) and body weight gain ( $210 \mathrm{~g} /$ day), the second phase to still increasing body weight $(96 \mathrm{~g} /$ day) but decreased voluntary food intake, and the third phase to stable body weight associated with decreased food intake. This suggests the existence of a "set point " for body weight in ruminants ; an animal might adapt its food intake to reach and maintain this " set point ". Similar results were achieved in a previous long-term experiment in which the sheep were maintained under constant temperature and daylight.

Loss of appetite with fatness during ad libitum feeding was observed in sheep by Foot (1972), Graham (1969) and Schinckel (1960) but the animals did not reach a "set point " for body weight. Forbes (1977), using a model for predicting the voluntary food intake of sheep in relation to metabolizable energy requirements, postulated the existence of a " set point " for body weight, but at a very high level. Our sheep seemed to reach that constant body weight when their initial weight had doubled. Blaxter and Gill (1979) reported that growing sheep fed at libitum with a pelleted died needed about 40 months to reach 95 p. 100 of their asymptotal weight. Moreover, the food intake was the same over a period of years.

At the beginning of our experiment, the body weight of the sheep, fluctuating around $50-60 \mathrm{~kg}$, was mainly composed of water $(48 \mathrm{~kg}$ ) and protein $(12 \mathrm{~kg})$ since body fat content represented only 3-15 p. 100 of the live weight. Comparable values were found by Doizé et al. (1979 b) for previously depleted lean sheep. When compared with the previously identical control sheep $(32.9 \mathrm{~kg}$ of water, $9.1 \mathrm{~kg}$ of protein and $2.1 \mathrm{~kg}$ of mineral matter), the experimental sheep showed a rapid initial body gain of non-fat constituents $148.0 \mathrm{~kg}$ of water, 
$12.9 \mathrm{~kg}$ of protein and $3.1 \mathrm{~kg}$ of mineral matter at the 3rd experimental week) when passing from the maintenance diet to ad libitum feeding with part of the water content being lost later in the experimental period. The differences in body composition in the present study mainly reflect an increase in the reticulo-rumen content. After this period, no change was found in the amount of water, protein, lean or mineral matter. Expressed on a p. 100 of live weight basis, these non-fat fractions decreased due to increased body fat. Similar results were obtained by Doizé et al. (1979 b). After the initial changes, fat represented the only long-term labile component of the adult body.

Very small adipocytes, which are difficult to identify, may have been confused with small lipid droplets. Some larger cells were probably broken by collagenase incubation. In our results, the small cells (S1) were probably overestimated and the larger cells (S7 to S12) underestimated. In spite of this technical problem, the present study clearly demonstrates a change in the adipocyte size frequency distribution in ad libitum fed sheep.

From the first observation (3rd week of ad libitum feeding) on, the experimental group showed a higher proportion of small cells but the increase was particularly evident in experimental weeks 14 and 18 , corresponding to the beginning of phase 2. Thereafter a slight decrease was noted but the rate of S1 adipocyte size remained high until the end of the test. The proportion of medium-sized cells (S2, S3, S4) decreased until the 18th week, followed by stable values. The proportion of the larger cells (S5 to S9) showed an increment between experimental weeks 14 and 26 which was responsible for the increase of the mean fat cell weight; this proportion then remained stable during the last three observations.

Contrary to the observations of Hood and Thornton (1979), our results indicate that feeding adult sheep ad libitum induces both hypertrophy and hyperplasia of the adipose cells. The high proportions of small adipocytes might result from an increase of the fat cell replication or from the lipid filling of the preadipocytes. Klyde and Hirsch (1979) demonstrated that in rats the diet induced an increase in the cell number as a consequence of cellular proliferation. Moreover, Kasubuchi et al. (1979) observed that the adipose cells diminished during malnutrition in mice and that they proliferated during the feeding state. These findings reinforced the impresssion that ad libitum feeding induced a proliferation of the adipocytes rather than an enlargement of the preadipocytes. The rate at which the adipose tissue in the overfed sheep synthesized lipid seemed to be influenced by the intake level and the fattening state.

We propose the hypothesis that feeding animals ad libitum induces the adipose tissue to increase its potential for lipid filling, resulting in a high proportion of small cells and an increase in body fat in the first fattening phase. The decrease of voluntary food intake associated with a stable body fat content corresponded to the appearance of large cells. The presence of a certain number of large adipocytes in the adipocyte compartment could be a local signal related to the "set point 》 for body weight.

The profile of mean fat cell weight was investigated in obese humans (Hirsch and Knittle, 1970 ; Salans et al., 1973), genetically obese mice (Johnson 
and Hirsch, 1972) and Zucker rats (Cleary et al., 1980 ; Johnson et al., 1971). The only recent studies on adipocyte size frequency distribution were realized on growing pigs (Mersmann et al., 1975) and on Zucker rats (Kaplan et al., 1980). No information is available concerning long-term ad libitum feeding effects on fat cell weight and morphology.

The results of the present experiments suggest that food intake is related to fatness. The food intake of each sheep was gradually adjusted to maintain body fat constant within a preferred range, and each sheep achieved its own body weight " set point".

This suggests the existence of a feedback system regulating long-term feeding behaviour. The adipose tissue might generate signals proportional to the quantity of fat stored or, because of its greater stability by the end of the experiment, proportional to the fat content of the body.

Previous studies (Peters, 1974 ; Panksepp, 1975 ; Holm et al., 1978 ; Keesey et al., 1979 ; Peters et al., 1979 a, b ; Corbett and Keesey, 1980) have led to the proposition of a neural "set point ». Many mathematical theories have been advanced to explain the control of body weight. The theory of Wirtshafter and Davis (1977) takes no account of a neural "set point ", and the authors are not convinced of the existence of a body weight "set point ". One of their arguments is that rats can be rendered obese by offering high-fat diets (Kanarek and Hirsch, 1977) or highly palatable diets (Faust et al., 1978). However, Kratz and Levitsky (1979) recently demonstrated that rats having free access to different foods presented in separate cups regulate their intake, and that the foods are without effect on final body weight. Reddingius' (1980) model argues the existence of feedback models and is thus more suited to an explanation of long-term control of food intake. The exact composition of the signal mediator between the central nervous system and the body fat reserves is still not well known.

Apparently, some interrelationships exist between voluntary food consumption on the one hand and body weight, body composition and adipose tissue morphology on the other. In the sequel to this study, we have tried to determine if some blood substances could act as mediators between these factors.

Reçu en avril 1982.

Accepté en août 1982.

Acknowledgements. - The authors would like to thank Dr. Schifflers of the Facultés Universitaires at Namur for his generous help with the statistical analysis. This work was supported by the Institut pour I'Encouragement de la Recherche Scientifique dans I'Industrie et l'Agriculture (IRSIA), rue de Crayer, B-1050 Brussels, Belgium.

Résumé. Effets à long terme d'une distribution illimitée d'aliments sur les ingestions volontaires, le poids vif, la composition corporelle et la morphologie du tissu adipeux.

Une expérience de longue durée a été réalisée sur des brebis Suffolk adultes. Le groupe expérimental était nourri à volonté et comparé à un groupe témoin recevant une ration destinée à couvrir les besoins énergétiques d'entretien. Les évolutions du poids vif et des ingestions volontaires d'aliments peuvent être divisées en trois phases. Après une période de transition (préphase), la première phase est caractérisée par une ingestion 
volontaire ( 3 à 3,5 fois le niveau des animaux témoins) et des gains en poids (plus de $200 \mathrm{~g} /$ jour) élevés. Durant la seconde phase, une augmentation plus lente du poids vif est associée avec une diminution des ingestions. Durant la dernière phase, le poids vif reste stable et les ingestions diminuent légèrement. Plus de 6 mois sont nécessaires pour que les animaux atteignent une stabilité pondérale.

Au cours de la préphase, une importante augmentation de l'eau corporelle est observée. Par la suite, l'alimentation ad libitum induit un dépôt de graisses dont la concentration augmente de 9 à 37 p. 100 du poids vif. Les quantités corporelles d'eau, de protéines et de matières minérales restent inchangées, mais les teneurs relatives (p. 100 du poids vif) de ces constituants diminuent. Le poids vif se stabilise pour chaque animal à un niveau particulier de graisses $(25$ à $50 \mathrm{~kg}$ ). Les teneurs relatives de ces substances sont moins variables ( 35 à $42 \mathrm{p} .100$ du poids vif).

Les deux groupes de moutons ont, au cours des 18 premières semaines de distribution illimitée d'aliments, le même poids moyen pour les adipocytes $(0,15 \mu \mathrm{g})$. Entre le $18^{\mathrm{e}}$ et la $22^{\mathrm{e}}$ semaine, le poids augmente fortement chez les animaux nourris ad libitum $(0.37 \pm 0.15 \mu \mathrm{g})$ puis se stabilise.

La distribution des différentes classes d'adipocytes est unimodale et stable chez les moutons témoins tout au long de l'expérience. Les adipocytes des moutons expérimentaux évoluent vers une distribution bimodale : la proportion de petites cellules augmente (S1), celle des adipocytes de taille moyenne (S4, S5) diminue et de grands adipocytes (S6, D9) apparaissent.

Ces résultats paraissent indiquer que des interrelations étroites existent entre les ingestions volontaires d'aliments d'une part et d'autre part le poids vif et la composition corporelle (état d'engraissement) des animaux.

\section{References}

BELL F. R., 1976. Regulation of food intake. Proc. Nutr. Soc., 35, 63-67.

BLAXTER K. L., GILL J. C., 1979. Voluntary intake in sheep and equilibrium body weight in sheep. Proc. Nutr. Soc., 38, 150A.

BOUCHAT J. C., DOIZE F., PAQUAY R., 1980. Effects of fasting on blood composition and nitrogen losses in the adult sheep depending on previous diet and body weight. Reprod. Nutr. Dévelop., 20, 77-92.

BOUCHAT J. C., DOIZE F., PAQUAY R., 1981. Influence of diet and prolonged fasting on blood lipids, ketone bodies, glucose and insulin in adult sheep. Reprod. Nutr. Dévelop., 21, 69-81.

CLEARY M. P., VASSELLI J. R., GREENWOOD M. R. C., 1980. Development of obesity in Zucker obese $(\mathrm{fa} / \mathrm{fa})$ rat in absence of hyperphagia. Am. J Physiol., 238, 284-292.

CORBETT S. W., KEESEY R. E., 1980. Digestibility in male rats with lateral hypothalamic lesions. Physiol. Behav., 24, 1165-1168.

DOIZÉ F., BOUCHAT J. C., PAQUAY R., 1979 a. Diurnal changes in blood ketone bodies, glucose and lipids according to energy intake in adult sheep. Ann. Biol. anim. Bioch. Biophys., 19, 393-404.

DOIZE F., DE WILDE R., PAQUAY R., 1979 b. Estimation de la composition chimique du mouton adulte. Ann. Zootech., 28, 393-406.

FAUST I. M., JOHNSON P. R., STERN J. S., HIRSCH J., 1978. Diet-induced adipocyte number increase in adult rats : a new model of obesity. Am. J. Physiol., 235, 279-286.

FOOT J. Z., 1972. A note on the effect of body condition on the voluntary intake of dried grass wafers by Scottish blackface ewes. Anim. Prod., 14, 131-134.

FORBES J. M., 1977. Interrelationships between physical and metabolic control of voluntary food intake in fattening, pregnant and lactating mature sheep : a model. Anim. Prod., 24, 91-101.

GRAHAM N. C. Mc., 1969. The influence of body weight (fatness) on the energetic efficiency of adult sheep. Austr. J. agric. Res., 20, 375-385.

HIRSCH J., KNITTLE J., 1970. Cellularity of obese and nonobese human adipose tissue. Fed. Proc., 29, 1516-1521.

HIRSCH J., GALLIAN E., 1968. Methods for the determination of adipose size in man and animals. J. Lipid Res., 9, 110-119. 
HOLM H., L $\varnothing \vee \varnothing$ A., HERSTVEDT B.E., 1978. Protein depletion and energy retention in rats with ventromedial hypothalamic lesions. Nutr. Metab., 22, 22-31.

HOOD R. L., THORNTON R. F., 1979. The cellularity of ovine adipose tissue. Aust. J. agric. Res., 30, 153-161.

JOHNSON J. H., ELISSALDE M. H., CLARK D. E., 1977. Technique for sampling subcutaneous fat from the tailhead of sheep. Am. J. vet. Res., 38, 1635-1636.

JOHNSON P. R., HIRSCH J., 1972. Cellularity of adipose depots in six strains of genetically obese mice. J. Lipid Res., 13, 2-11.

JOHNSON P. R., ZUCKER L. M., CRUCE J. A. F., HIRSCH J., 1971. Cellularity of adipose depots in the genetically obese Zucker rat. J. Lipid Res., 12, 706-714.

KANAREK R. B., HIRSCH E., 1977. Dietary-induced overeating in experimental animals. Fed. Proc., 36, 154-158.

KAPLAN M. L., TROUT J. R., LEVEILLE G. A., 1976. Adipocyte size distribution in ob/ob mice during preobese and obese phases of development. Proc. Soc. exp. Biol. Med., 153, 476-482.

KAPLAN M. L., TROUT J. R., SMITH P., 1980. Adipocyte size distribution in fa/fa rats during development. Metabolism, 29, 333-339.

KASUBUCHI Y., MINO M., YOSHIOKA H., KUSUMOKI T., 1979. An autoradiographic study of new fat cell formation in adipose tissue in adult mice during malnutrition and refeeding. J. Nutr. Sci. Vitaminol., 25, 419-426.

KEESEY R. E., MITCHEL J. S., KEMNITZ J. W., 1979. Body weight and body composition of male rats following hypothalamic lesions. Am. J. Physiol., 237, 68-73.

KLYDE B. J., HIRSCH J., 1979. Increased cellular proliferation in adipose tissue of adult rats fed a high-fat diet. J. Lipid Res., 20, 705-715.

KRATZ C. M., LEVITSKY, D. A., 1979. Dietary obesity : differential effects with self-selection and composite diet feeding techniques. Physiol. Behav., 22, 245-249.

LAVAU M., SUSINI C., KNITTLE J., BLANCHET-HIRST S., GREENWOOD M. R. C., 1977. A reliable photomicrographic method for determining fat cell size and number : application to dietary obesity. Proc. Soc. exp. Biol. Med., 156, 251-256.

MERSMANN H. J., GOODMAN J. R., BROWN L. J., 1975. Development of swine adipose tissue : morphology and chemical composition. J. Lipid Res., 16, 269-279.

PANKSEPP J., 1975. Central metabolic and humoral factors involved in the neural regulation of feeding. Pharmac. Biochem. Behav., 1, 107-119.

PETERS R. H., 1974. Effects of ventromedial hypothalamic lesions on restricted feeding behavior in rats. Physiol. Behav., 12, 761-766.

PETERS R. H., GUNION M. W., WELLMAN P. J., 1979 a. Influence of diet palatability on maintenance feeding behavior in rats with dorsolateral tegmental damage. Physiol. Behav., 23, 685-692.

PETERS R. H., WELLMAN P. J., GUNION M. W., 1979 b. Experimental obesity syndrom in rats : influence of diet palatalitity on maintenance body weights. Physiol. Behav., 23, 693-699.

REDDINGIUS J., 1980. Control theory and the dynamics of body weight. Physiol. Behav., 24, 27-32.

ROBELIN J., 1973. Estimation de la composition corporelle des animaux à partir des espaces de diffusion de l'eau marquée. Ann. Biol. anim. Bioch. Biophys., 13, 285-305.

RODBELL M., 1964. Metabolism of isolated fat cells. 1. Effects of hormones on glucose metabolism and lipolysis. J. biol. Chem., 239, 375-380.

SALANS L. B., CUSHMAN S. W., WEISMANN R. E., 1973. Studies of human adipose tissue. Adipose cell size and number in nonobese and obese patients. J. clin. Invest., 52, 929-941.

SCHINCKEL P. G., 1960. Variation in feed intake as a cause of variation in wool production of grazing sheep. Aust. J. agric. Res., 11, 585-594.

VAN ITALLIE T. B., SCHUPT-SMITH N., QUATERMAIN D., 1977. Short-term and long-term components in the regulation of food intake : evidence for a modulatory role of carbohydrate status. Am. J. clin. Nutr., 30, 742-757.

WIRTSHAFTER D., DAVIS J. D., 1977. Set points, settling points, and the control of body weight. Physiol. Behav., 19, 75-78. 